of the didactic system of cognitive activity in modern institutions of postgraduate pedagogical education and highlighting the basic provisions on the vectors of training of their teachers-engineers.

Key words: digitalization, digital transformation, regularities, scientific approaches, digital didactics, pedagogical engineering, teacher-engineer.

Дата надходження статті: 22.01.2021 p.

Рецензент: доктор педагогічних наук, доцент Примакова В. В.

У, ДК 821.161.2-193.3.09(477.73)

DOI https://doi.org/10.37915/pa.vi48.197

Баденкова В. М. *, orcid.org/0000-0002-8024-2434

Родіонова I. Г., orcid.org/0000-0002-3020-8764

\title{
ВИВЧЕННЯ ЖАНРУ СОНЕТА СТУДЕНТАМИ-ФІЛОЯОГАМИ (НА МАТЕРІАЛІ ТВОРЧОСТІ С. КРИЖАНІВСЬКОГО)
}

У статті акцентовано, що в сучасному глобалізованому світі все важче ідентифікувати себе як частину окремої етнічної спільноти $і$ тому важливим складником у системі національно-мовного виховання особистості посідае краєзнавство. Науковці наголошують, що літературне краєзнавство є педагогічною категорією, стійким педагогічним явищем, системним структурним компонентом сучасної літературної освіти. Незважаючи на значні напрацуювання з проблеми, різноманіття аспектів літературного краєзнавства в навчальновиховному процесі, відчутною є недостатня кількість розробок текстуального вивчення творів письменників Миколаӥвщини, ще повинно було б допомогти студентам осягати глибинну сутність спадщзини митців краю, поглиблювати знання про його історію, його найвидатніших земляків, а також сприяти формуванню загальнолюдських духовних изінностей, крім того, дасть змогу майбутнім вчителям-філологам поглибити теоретичні знання з літературознавства.

У статті актуалізовано поняття «сонет», визначено його види, охарактеризовано сонетну традиціюо в українській літературі, а також звернено увагу на особливості вивчення ццих форм вірша на матеріалі поетичної практики одного з найвідоміших літературних діячів не тільки Миколаӥвщини, але й Украйни ХХ ст. С. Крижанівського, як-от сонет з кодою, сонет без рим, подвійний сонет, сонет-акростих та ін. У пропонованій працзі відзначено, що творчість мития тривалий час не висвітлювалась у критичних джерелах, не використовувалися його поетичні знахідки у вузівській та відповідно у шкільній практиці, зокрема його сонети, для ідейно-естетичного розвитку учнів. Установлено, щьо митець єавтором 14 різновидів сонетів, вивчення яких актуальне в теоретичному та практичному аспектах. Схарактеризовано зміст стилістико-мовної роботи студентів із поетичним текстом у процесі його вивчення. Зроблено висновок, щзо оптимальна організація навчальних занять дозволить студентам детальніше осмислити сонетну форму, творчість поета уконтексті не лише літератури рідного краю, а й загальноукрайнського літературного процесу, усвідомити вартісність духовних та естетичних цінностей, сприятиме формуванню компетентного читача.

Ключові слова: літературне краєзнавство, сонет, виховання національно-мовної особистості, творчість С. Крижанівського, поетична форма.

*(C) Баденкова В. М.

“(C) Родіонова I. $Г$.

U3 105 
Постановка проблеми. Входження України до европейського простору передбачає перебудову змісту й форм освіти, оскільки для мододої дюдини в сучасному глобалізованому світі все важче ідентифікувати себе як частину окремої етнічної спільноти. Сучасні педагогічні, методичні, лінгвістичні дослідження та концепції, зокрема «Концепція національно-патріотичного виховання дітей і молоді», актуалізують питання мовно-національного виховання особистості як пріоритетний напрям національної системи виховання засобами рідного слова в сучасних умовах розвитку української державності, відродження національної культури та освіти.

Відповідно оновдюються методи організації навчальної роботи, а також удосконалюються форми та шляхи вдосконалення навчально-виховного процесу та використання краєзнавчого матеріалу як засобу формування загальнолюдських та національно-патріотичних почуттів молоді.

У складній системі сучасного навчально-виховного процесу чільне місце посідає вивчення літератури рідного краю. Принагідно відзначимо, що в науковій дітературі уживаним є поняття «літературне краєзнавство» (саме 3 такою назвою пропонується спецкурс в освітньо-професійній програмі підготовки майбутніх вчителів української мови i дітератури Миколаївського національного університету імені В. О. Сухомлинського), а в шкільній практиці «література рідного краю», а також чинною програмою з української літератури передбачені у формі спеціально відведених уроки, на яких учнів ознайомлюють із творчістю та культурно-літературним життям краю. Чим гдибші й змістовніші будуть знання студентів-філологів про рідний край та духовну спадщину його видатних дюдей, тим більше згодом буде можливостей для формування загальнолюдських та національно-патріотичних почуттів у їхніх майбутніх учнів - школярів.

Аналіз досліджень. У довідковому виданні «Методика викладання літератури: Термінологічний словник» сформульоване наступне визначення: «Краєзнавство літературне - галузь дітературознавства, яка досліджуе зв'язки між істориколітературним процесом (у межах розвитку національних літератур) і літературною історією, літературним середовищем окремих місцевостей нашої країни», а також зазначається, що «творчі здобутки письменників, діяльність яких пов'язана з окремими місцевостями», повинні подаватися на тлі досягнень національної і світової літератури» [6, с. 50].

Вивчення педагогічних засад літературного краєзнавства відбувалося в різні періоди розвитку освіти, педагогічної думки. Це, зокрема, праці таких видатних вітчизняних науковців та культурно-освітніх діячів, як Г. Ващенко, А. Волошин, О. Духнович, А. Макаренко, С. Русова, В. Сухомлинський, К. Ушинський, С. Шацький та ін., що наголошували на необхідності національного виховання. У науковій літературі педагогічне поняття «краєзнавство» закріплюеться на межі 20-х pp. XX століття. На сучасному етапі літературне краєзнавство $є$ стійким педагогічним явищем i важливим структурним компонентом системи сучасної дітературної освіти студентів та учнів, що аналізуеться в дослідженнях, присвячених розкриттю різноманітних аспектів літературного краєзнавства - переважно шкільного - у навчально-виховному процесі (Л. Башманівська, Г. Білавич, Т. Бондаренко, В. Бугрій, І. Волинець, М. Горда, А. Аисенко, В. Лящук, Є. Пасічник, Т. Посадковська, Л. Прокоф'єва, В. Романько, О. Фесенко, В. Шуляр, В. Шульженко, М. Янко та ін.), визначаються його складники, зміст, методи, прийоми і засоби, які забезпечують громадянське, патріотичне, морадьно-етичне, естетичне виховання, низку вмінь і навичок, необхідних для загальнокультурного розвитку учнів, адаптації їх до життя в певному соціальному середовищі. Нині у світовій практиці ефективність освіти пов'язується з реалізацією компетентнісного підходу, зокрема, формуванням соціокультурної, лінгвокраєзнавчої компетентностей.

Так, А. Аисенко у дисертації «Методика використання дітературного краєзнавства в системі підвищення кваліфікації вчителів-словесників» (2002) теоретично обгрунтувала

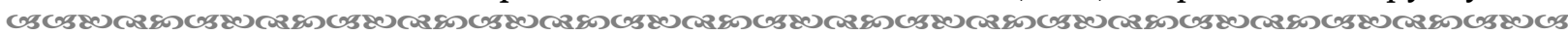
106 
й експериментально перевірила методичне забезпечення використання иітературного краєзнавства у відповідній системі, описала концептуальні основи та критерії формування змісту літературного краєзнавства, розробила систему методів та прийомів викладання літературного краєзнавства на основі інноваційних педагогічних технологій. Вона вказала, що література рідного краю, «попри повсякденне акцентування уваги на відродженні націонадьної духовності, часто залишається відстороненою від навчально-виховного процесу у вищих навчальних закладах», що призводить, на їі думку, до непрофесійного використання учителями краєзнавчого матеріалу на уроках літературного читання [4, с. 102].

Аналіз питання теорії і практики викладання засвідчуе наявність суперечностей між завданнями, що передбачені навчальною програмою вищої та базової шкоди, та недостатньо розробленим методичним фондом використання літературного краєзнавства. Зняття цих суперечностей потребує ще докладного всебічного вивчення, створення нового науково-методичного супроводу цього процесу. Оскільки, як слушно зауважує О. Слижук, організація сприйняття творів класиків української літератури, що є взірцями красного письменства, «вимагає ретельної підготовчої роботи, входження в культурно-історичні умови епохи, у яку був написаний твір. Часто реалії суспільного життя також потребують додаткових знань з історії, а стиль написання твору - 3 теорії літератури та літературознавчих вчень [7, с. 75].

Метою статті є обгрунтування специфіки вивчення форми сонета студентамифілологами на матеріалі поетичного доробку С. Крижанівського.

Виклад основного матеріалу. Навчальні заняття 3 літературного краєзнавства мають допомогти студентам осягати гдибинну сутність спадщини митців Миколаївщини, поглиблювати знання про ії історію, іï найвидатніших земляків, а також сприяти формуванню загальнолюдських духовних цінностей, крім того, погдибити майбутнім учителям-філологам теоретичні знання з дітературознавства.

У вступі до вивчення теми викладач має нагодосити, що в особі С. А. Крижанівського поєдналися не тільки поет і критик, а ще історик і теоретик літератури XX ст. За своє творче життя митець видав 20 науково-теоретичних праць та 20 збірок поезії. Поезію 30-40-х років нерідко вважають фальшивою, нещирою. У ній нібито проявився награний оптимізм, замовчувалися труднощі індустріалізації, вивихи колективізації, також уникалися «дратівдиві» теми голоду 1933 р. та репресій 19371938 рр. Дійсно, ці теми були забороненими для дітератури і старанно викреслювалися 3 нашої історії. А на початку свого творчого шияху С. Крижанівський писав оптимістичні, націлені на добро, поезї, вірив у міф Міста-Сонця, писав із вірою в щасливе майбутне свого покоління, у світле майбуття України й всього людства. Віра ця була щирою, вона зумовлювалася молодістю автора, суспільною атмосферою тих літ, коли Україна жила пафосом великих соціальних змін.

Це й призвело до того, що творчість поета тривалий час не висвітдювалась у критичних джерелах, не використовувались у викладацькій практиці його поетичні знахідки. Небагато джеред містять відомості про життя та творчість митця, це, зокрема, нариси В. Бойченка, $А$. Старовойт у виданні «Шевченківський енцикдопедичний словник Миколаївщини: 200-літтю від дня народження Тараса Шевченка присвячується» (2014), М. Шитюка в навчальному посібнику «Слава і гордість Миколаївщини : 75-річчю утворення Миколаївської області присвячується» (2012). Найбільш повними є відомості, подані в автохарактеристиці «Перегортаючи сторінки», уміщеній у збірці віршів «Дітопис» (1991) [3, с. 339-353]. Обійдена увагою творчість митця у навчально-методичному виданні знаних науковців та вчителів-методистів В. Шуляра, В. Купцової «Дітература рідного краю : програма для закладів загальної середньої освіти (5-11 класи)» (2020), у якому запропоновані матеріали для вивчення дітературних надбань Миколаївщини. Проте вважаємо, що вивчення творчого доробку митця важливе для ідейно-естетичного розвитку учнів, адже він писав і вірші-роздуми,

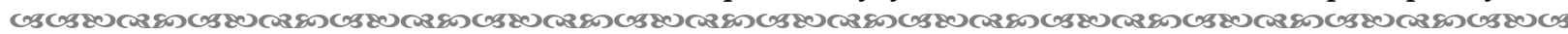
107 
і відгуки на важдиві подітичні події, задумувався над проблемами екології, удавався до філософського осмислення життя. Уявлення про рідний край, його природу дають такі шедеври, як «Березань», «Миколаїв», «Моєму місту». Тому творчий доробок С. Крижанівського, на нашу думку, дає широкі можливості для формування уявлення про українську літературу 30-60-х років ХХ століття в учителів-словесників, засвоєння особливостей цього періоду під час вивчення літератури рідного краю.

Випробувавши себе майже у всіх поетичних та ліро-епічних жанрах (ода, елегія, пісня, поетична притча, жарти й приповідки, поема, байка тощо), письменник у різні роки творчості вдавався до форми сонета. Важдиво коротко зупинитися на питанні історичного розвитку сонета, зокрема нагадати визначення: сонет - «діричний твір твердої строфічної форми, який складається з чотирнадцяти рядків п'ятистопного або шестистопного ямба (хоч відомі чотиристопні ямби, сонетино), тобто двох відкритих чи закритих катренів із перехресним римуванням і двох триверсів тернарного римування за основною схемою абаб абаб ввг ддг» [5, с. 415]. Виникла ця старовинна канонічна форма вірша в XIII ст. у Сицилії. Данте Аліг'єрі (XIII ст.) одним з перших написав книгу сонетів «Нове життя». Найбільшого розвитку сонет досяг у творчості Франческо Петрарки (XIV ст.), який остаточно встановив число віршів і порядок рим у творі. Форми сонета в італійській літературі поступово набувала вся інтимна та філософська лірика. Із часом італійці почали називати сонет «чотирнадцятивіршовим Прокрустовим ложем почуття й думки». Із XVI ст. сонет проникає до Франції, з ним пов'язана творчість П. Ронсара (1527-1585): відомо 709 його сонетів. У добу кдасицизму сонет був єдиним із літературних надбань, чиє право на існування стверджувалося теоретиками літератури: «Добре написаний сонет варт цілої поеми» (Н. Буало. Переклад I. Качуровського) [1, с. 114]. Із XVII ст. сонет уже використовується в Англії, де В. Шекспір і В. Вордсворт проявили себе як геніальні творці сонета. Взагалі саму форму сонета слід розглядати як філософську, бо в його композиції вбачається гегелівська тріада: перший чотиривірш зазвичай містить у собі тезу, другий - антитезу, а тривірші - синтезу (т. зв. «сонетний замок»). Рими мають бути точні і дзвінкі, кожна строфа - синтаксично викінченою.

Треба згадати і про види сонета (за класифікацією І. Качуровського): imaхiŭськофранцузький, класичний (складається 3 двох катренів і двох терцетів), містить 5 рим, що розташовані у такому порядку: абба абба ввг дгд; жодне слово (за винятком) службового в класичному сонеті не може повторюватися; англійський або шекспірівський (складається 3 трьох катренів і одного дистиха), у ньому катрени не пов'язані між собою фонетичним уподібненням рим, і двовірш із парним римуванням; інкоди, крім двох основних різновидів сонета, виділяють третій: німецько-російський, його особливості виявляються в тому, що за внутрішньою композицією і системою римування такий сонет повністю повторюе нормативи італійсько-французького, але замість силабічного вірша, характерного для класичного сонета, у німецько-російському використовуеться силабо-тонічний (5 або 6-ти стопний ямб) вірш. Такий сонет характерний і для української поезії, найвизначнішими майстрами якого стали I. Франко, Деся Українка, Є. Маланюк. В українських поетів сонет набуває тієї довершеності й гармонійності, філософської глибини й інтелектуальної напруги, котрі стали окрасою української поезії, засвідчивши природну реакцію поетів на етнографізм та формальну одноманітність. Варто нагадати про поетичну школу «неокласиків» (М. Зеров, М. Рильський, М. Драй-Хмара, П. Филипович та Юрій Клен), які, на противагу багатьом «революційним поетам» та їхнім угрупуванням («Гарт», «Пролеткульт», Аспанфут та інші), протиставили провінціалізмові «новітніх» поетів строгість і ясність думки (кларизм), чистоту й милозвучність сонета.

Продовжив сонетну традицію в українській літературі середини XX ст. С. Крижанівський: десять творів цього жанру (датовані 1946, 1959 та 1960 рр.) присвятив традиційній дюбовній тематиці. Пропонуємо розглянути цикл «Сонети про любов і

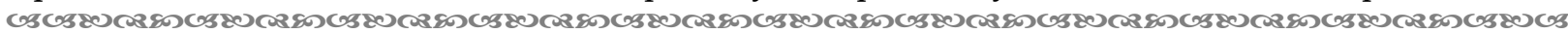
108 
розлуку» (книга «Ще не вечір»). Викладач має наголосити, що, по суті, ці філософськи заглиблені твори містять оригінальний погляд на кохання, нешаблонний поворот думки, втілений у таких поетичних засобах, що передають атмосферу щирості у вираженні почуттів діричного героя. Усі вони написані п'ятистопним ямбом, строфи римуються схематично: абба абба ввг гдд або абаб абба ввг ддг, тобто використано п'ять рим. Окрім того, вказані сонети також акумулюють і канонічні нормативи щодо змісту та його компонування.

Післятекстове завдання: Скласти графічні схеми поетичних фрагментів сонетів. Визначити віршовий розмір. Пояснити, чи є взаємозалежність віршового розміру й тематики твору? Аргументовано довести думку.

Подекуди в сонетах С. Крижанівського проступає характерний елемент парадоксадьності, який розвивається тезою, оформленою риторичним запитанням, продовжується антитезою (за допомогою того ж засобу поетичного синтаксису) і розкривається несподіваним висновком, властивим, скоріше, для психологічної новели, як у сонеті «Було багато зустрічей, розлук» [2, с. 194]. Усі десять «Сонетів про любов і роздуку» завершуються риторичним запитанням, звертанням чи окдиком, що вкупі 3 відповідним розміром засвідчують виразний драматичний характер стильової манери поета.

На основі сонета виникла низка довільних і ускладнених форм, які чи не вперше в українській літературі спостерігаємо у «Сонетарії» С. Крижанівського. У цьому циклі зі збірки «Формула щастя» поетом укладено 14 різновидів сонета. По виході у світ цього поетично-експериментального циклу, С. Крижанівський розмірковував: «Я не перебільшую своїх успіхів у сонетописанні, хоч написав десь біля 50-ти сонетів. Куди мені проти таких сонетярів, як М. Рильський і М. Зеров, як Б. Тен і Д. Павдичко. Але ядав у сонетарії щось 14 різновидів сонета, в тому числі й різні його дивогдяди та новації» [3, с. 349].

Пропонуємо розглянути такі сонети С. Крижанівського із поетичного циклу «Сонетарій»: «Кредо Шекспіра», «Катарсис», «Суперечка», «Через терни - до зірок», «Докір», «Весна-володарка», «Василю Стефанику», «Іванові Котляревському на двохсотріччя», «Розмова $з$ рецензентом», «Двоїстість» та з'ясувати, до яких із сонетів автора можна застосувати наступні жанрові визначення: «канонічний», «сонетоїд», «шекспірівський», «білий, «кульгавий», «перевернутий», «безголовий», «половинний», «сонет 3 хвостом», «сонет на дві рими», «подвійний сонет», «сонет-акростих 3 кодою», «сонет-діалог» тощо. При цьому радимо укласти словничок літературознавчих термінів (інформацію див. за джерелом [5, с. 417-418]): 1) «перевернутий сонет» (у якому терцети випереджають катрени, або стоять поміж ними); 2) «хвостатий сонет» (один або декілька «зайвих» тривіршів (в італійському варіанті тривірш римується так: один короткий рядок римується 3 14-тим рядком сонета і два довгі - між собою, це - хвістритурнель)); 3) сонет із кодою (до традиційного набору катренів і терцетів доданий ще один - 15-тий рядок); 4) сонет питань $і$ відповідей (сув' язь із сонетів, своєрідний діалог, коди один автор пише вірш, а другий відповідає йому поезією на ті самі рими); 5) подвійний сонет (після кожного непарного рядка катрена і парного рядка терцета вставляється укорочений рядок, або два сонети, поєднані у цикд); 6) «половинний сонет» (який складається із 1 катрена і 1 терцета, тобто має 7 рядків); 7) «безголовий сонет» (у якому немає першого катрена, тобто складається із 10 рядків); 8) «суціільний сонет» (написаний із використанням двох рим); 9) «кульгавий сонет» (3 укороченими четвертими рядками в катренах); 10) сонет-акростих (сонет, у якому перші літери кожного рядка утворюють слово або речення, найчастіше ім'я того, кому присвячується вірш); 11) сонет-буріме (поезія, написана на задані рими); 12) білий сонет (не має рими) та ін.

Образність сонетів досліджується в нерозривності їх форми і змісту, в єдності частин і цілого, що означає найактивніше залучення у сферу аналізу елементів

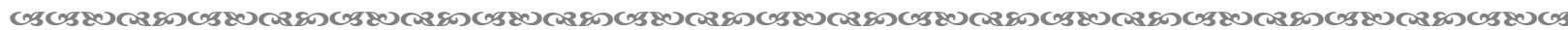
109 
їх змістовної форми. Високий рівень мовної компетентності в опрацюванні студентами художніх творів забезпечується стилістико-мовною роботою, що є важдивою складовою вивчення курсу «Дітературне краєзнавство». Мова певної епохи представляє ряд історичних та соціальних нашарувань, що мають різну цінність і мають різну художню дієвість. Архаїзми, просторіччя, неологізми, стилістичні засоби використовуються автором в якості художнього прийому. Звернімо увагу на деякі 3 них.

Перифраз - це розгорнута метонімія, коли назва предмета замінюється описовим виразом, є засобом логічного уточнення першого значення, а також образної та експресивно-оцінної характеристики. Індивідуально-авторські перифрази є ефективним засобом конденсації думки та вираження суб'єктивного ставлення поета до змісту висловлювання: украйнська мова - украӥнський глас, дар дорогий [2, с. 242], весна-володарка, весна зелена - Надія на рожевому човні; Аюбов - володарка на білому коні, Надія, обіцянка нескінченна [там само, с. 240]; Дніпро - закутий Прометей [там само, с. 233]; сонет - модель душі поета / Не почуттів звичайний вінегрет, / А слова й мислей органічна сплета [там само, с. 230]. Миколаїв митець називає «Моє місто, мій давній друг», «місто юності моєї, / Моїх думок юнацььких і стремлінь», «місто-сонцестан». Часто автор веде діалог із своїм героєм: Василю Стефанику - Василю, отче, вчителю коханий [там само, с. 241]; до Котляревського - батьку, безсмертний [там само, с. 242], напр.: Іване, батьку, вчасно ти озвався [там само, c. 242].

У діриці 1960-х років відбувся несподіваний вибух метафоричного мислення, пов'язаний зі стрімким розвитком суспільної свідомості, науки та техніки. Степан Крижанівський за таких умов, звичайно, змінювався завдяки новим обставинам, новому життевому досвіду, природному внутрішньому розвитку, а відповідно, змінювався й характер його поезії: Душа моя - молекула полярна [2, с. 230]; музика сфер [там само, с. 236]. Актуалізується нова лексика, пов'язана з увагою до перемог країни в освоєнні космічних просторів: зірка [там само, с. 230], космонавти [там само, с. 235], ракети [там само, с. 234], кослос [там само, с. 233], Всесвіт [там само, с. 233], напр.: я славлю ваше золоте весілля - / Півсотні років ви побрались / I справили планети новосілля [там само, с. 235]

У сонетоїді «Сигнали» 1968 р. фіксуємо: другі планети, галактики туманні, космічний простір, косміяни. Автор вибудовуе синонімічний ряд на позначення істот позаземних цивілізацій: зелені чоловічки, косліяни, розумні створіння з галактик, спільники у радості і горі [2, с. 232, 292].

Пропонуємо здійснити спостереження над зміною семантики окремих виразів, напр. зелені чоловічки (сонет 1968 р.) [2, с. 232]. Етимологічна довідка: у 1967 році радіоастроном із Кембриджа Джоселін Белл Бернелл виявила переривчастий сигнал із постійною частотою імпульсів, що виходив від далекої зоряної системи і спочатку отримав робочу назву LGM від англійського little green men «зелені чоловічки». Також 16 вересня 1994 р. вийшов перший епізод другого сезону серіалу «Секретні матеріали» під назвою «Маленькі зелені чоловічки» (англ. «Little Green Men»). I нарешті у березні 2014 р. активізувався евфемізм зелені чоловічки для позначення військовослужбовців Збройних сил Російської Федерації у військовій формі без розпізнавальних знаків, які проводили таємні, на першому етапі часто не бойові, операції 3 захоплення і блокування стратегічних об’єктів в українському Криму під час російської окупації. В інтернет-джерелах назва зелені чоловічки також вживається на позначення екопоселенців або дауншифтерів, людей, які втекди від урбаністичного шаленого ритму, відмовилися від більшості благ сучасної цивілізації і живуть простим життям.

Закдючний етап вивчення сонета С. Крижанівського передбачає визначення основних особливостей жанру: досконала поетична форма, класичні види римування, цікаві спроби сонетного експерименту; філософічна настроєвість, логічна довершеність, пошуки душевної рівноваги, перипетії кохання, мудра простота життя, роль мистецтва в житті людини, конкретні, зримі образи, точність художніх засобів, поетичне слово ужите оригінально й свіжо. Принагідно зауважимо, що уміння поета інтимізувати

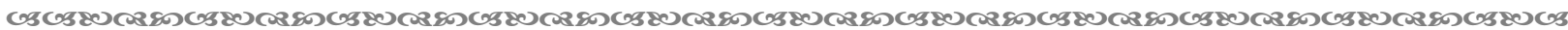
110 
обставини, події та явища життя стадо однією з характерних рис його сонета.

Висновки. Урахувавши попередні зауваги, доходимо висновку: сонет в поетичній практиці С. Крижанівського став не лише орієнтиром культурного ренесансу, а й полем поетичного експерименту, оптимальним засобом реалізації авторського світорозуміння. Запропонована методична модель організації навчального заняття дозводить студентам детальніше осмислити сонетну форму, творчість поета у контексті не лише літератури рідного краю, а й загальноукраїнського літературного процесу, усвідомити вартісність духовних та естетичних цінностей. Поезії С. Крижанівського дають уявлення про рідний край, його природу, людей, про суспільно-політичну атмосферу, а їх аналіз сприятиме формуванню компетентного учня-читача. Відтак предметом подальшого вивчення можуть стати пошуки нових форм організації навчальної та наукової діядьності майбутніх вчителів-філологів як для поглиблення знань із літератури, так i для виховання загальнолюдських і національних цінностей.

\section{Список використаних джерел:}

1. Качуровський І. Строфіка: підручник. Київ: Либідь, 1994. 272 с.

2. Крижанівський С. А. Берізка: вибрані поезії. Київ: Дніпро, 1971. 347 с.

3. Крижанівський С. А. Дітопис: вибране. Київ: Дніпро, 1991. 359 с.

4. Аисенко О. В. Методика використання дітературного краєзнавства в системі підвищення кваліфікації вчителів-словесників : дис. ... канд. пед. наук. К., 2002. 220 с.

5. Літературознавча енциклопедія: у двох томах / авт.-уклад. Ю.І.Ковалів. Київ : ВЦ «Академія», 2007. Т. 2. 622 с.

6. Ситченко А. А., Шуляр В. І., Гладишев В.В. Методика викладання літератури: термінологічний словник. Київ: Видавничий Дім «Ін Юре», 2008. 132 с.

7. Слижук О. А. Психолого-педагогічні аспекти сприйняття підлітками сучасної української літератури. Педагогічний альманах: зб. наук. пр./ редкол. Н. В. Кузьменко (гол. ред.) та ін. Херсон : КВНЗ «Херсонська академія неперервної освіти», 2019. Випуск 44. С. 72-78.

\section{References:}

1. Kachurovskyi, I. (1994). Strofika [The stanza]. Kyiv: Lybid [in Ukrainian].

2. Kryzhanivskyi, S. A. (1971). Berizka [Bindweed: selected poetry]. Kyiv: Dnipro [in Ukrainian].

3. Kryzhanivskyi, S. A. (1991). Litopys [Chronicle: selected writings]. Kyiv: Dnipro [in Ukrainian].

4. Lysenko, O. V. (2002). Metodyka vykorystannia literaturnoho kraieznavstva v systemi pidvyshchennia kvalifikatsii vchyteliv-slovesnykiv [Methods of using literary local lore in the system of philologists' professional development]. (Candidate's thesis). Kyiv [in Ukrainian].

5. Kovaliv, Yu. I. (Ed.). (2007). Literaturoznavcha entsyklopediia [Literary encyclopedia]. (Vols 1-2). Kyiv: VTs «Akademiia» [in Ukrainian]

6. Sytchenko, A. L., Shuliar, V. I., \& Hladyshev, V. V. (2008). Metodyka vykladannia literatury [Methods of teaching literature]. Kyiv: Vydavnychyi Dim «In Yure» [in Ukrainian].

7. Slyzhuk, O. A. (2019). Psykholoho-pedahohichni aspekty spryiniattia pidlitkamy suchasnoi ukrainskoi literatury [Psychological and pedagogical aspects of perception by adolescents modern Ukrainian literature]. Pedahohichnyi almanakh, 44, 72-78 [in Ukrainian].

Badenkova V. M., orcid.org/0000-0002-8024-2434

Rodionova I. G., orcid.org/0000-0002-3020-8764

\section{STUDY OF THE SONNET GENRE BY STUDENTS-PHILOLOGISTS} (ON THE MATERIAL OF S. KRYZHANIVSKY'S CREATIVE WORK)

The article emphasises that it is increasingly difficult to identify oneself as part of a separate ethnic community in today's globalized world and for this reason an important component in the system of national-language education of the individual occupies local lore. Scholars emphasise that the literary local lore is a pedagogical category, a stable pedagogical phenomenon, a systemic structural component of modern literary education. 
Despite significant work on the problem of diversity of aspects of literary local lore in the educational process, there is a lack of textual studies of writers of Mykolaiv region, which should have helped students to understand the deep essence of the heritage of artists of the region, deepen knowledge of its history, its outstanding fellow-countrymen and also to promote the formation of universal spiritual values. In addition, the study of such material will provide opportunities for future teachers of philology to deepen theoretical knowledge of literary studies.

The article actualises the concept of "Sonnet", defines its types, describes the sonnet tradition in Ukrainian literature and draws attention to the peculiarities of studying these forms of poetry on the material of poetic practice of one of the most famous literary figures not only Mykolaiv region but also Ukraine of the XX century by S. Kryzhanivskyi, such as the "Sonnet Reversed", Double Sonnet, Acrostic Sonnet, etc. It is noted in the proposed work that the artist's work has not been covered in critical sources for a long time, his poetic findings have not been used in university and school practice, in particular his sonnets for pupils' ideological and aesthetic development. It is established that the artist is the author of 14 varieties of sonnets, the study of which is relevant in theoretical and practical aspects.

The content of stylistic and linguistic work of students with a poetic text in the process of their study has been characterised. It is concluded that the optimal organisation of classes will give an opportunity for students to better understand the sonnet form, the poet's work in the context of not only the literature of the native land, but also the all-Ukrainian literary process, realise the value of spiritual and aesthetic values, contribute to the formation of a competent reader.

Key words: literary local lore, sonnet, national and linguistic personality development, creative work of S. Kryzhanivsky, poetic form.

\section{ТЕОРЕТИЧНІ ЗАСАДИ ФОРМУВАННЯ ОСВІТНЬО-НАУКОВОГО СЕРЕДОВИЩА ПРОФЕСІЙНОЇ ПІДГОТОВКИ МАЙБУТНІХ ФАХІВЦІВ ГОТЕЯЬНО-РЕСТОРАННОЇ СПРАВИ}

У статті представлено численні дослідження українських науковців щзоо професійної підготовки майбутніх фахівиів через створення відповідного освітнього середовища. Розглянуто визначення дефініцій «освітне середовище», «освітньо-наукове середовище», «психологічно безпечне освітньо-наукове середовище», «інклюзивне освітне середовище», «інформаційноосвітне середовище в умовах дистанциійної освіти», «хмаро орієнтоване середовище». Освітнвонаукове середовище професійної підготовки майбутніх фахівців готельно-ресторанної справи потрактуємо як природну або цзілеспрямовано створену сферу навчально-пізнавальної діяльності науково-педагогічних прациівників та здобувачів освіти, пов'язану з розвитком матеріально-технічної, освітньо-наукової та комунікативної складових, зорієнтовану на цілеспрямовану організацію та трансформацію фахової підготовки через формування змісту і засобів освіти для забезпечення ефективного освітнього процесу, освітнього розвитку особистості, забезпечення педагогічних умов, функціонування системи взаємин сторін, поєднаних спільною педагогічною та навчальною діяльністю. До структури освітньонаукового середовища професійної підготовки майбутніх фахівиів готельно-ресторанної справи

${ }^{*}(\mathrm{C}$ Бурак В. Г.

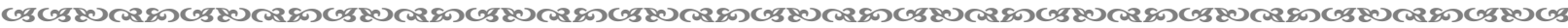

